\title{
Disintermediation: An Old Disorder With A New Remedy
}

\author{
R. ALTON GILBERT and JEAN M. LOVATI
}

IN

$\mathrm{N}$ the summer of 1977 , yields on short-term U.S. Treasury bills rose above the maximum interest rates that commercial banks and most thrift institutions are legally permitted to pay on passbook savings deposits. ${ }^{1}$ By the end of that year, interest rates on U.S. Treastry securities had risen above ceiling interest rates on time deposits with longer maturities. In the past, when market interest rates have risen above legal ceiling rates on time and savings deposits by similar margins, the growth of these deposits has slowed sharply. This is called disintermediation.

Thrift institutions provide a major source of residential construction and mortgage credit, and thus, disintermediation tends to reduce the supply of credit available to the housing market. Since residential construction is a major industry, and since the stabilization of housing construction has a high priority in public policy, disintermediation at thrift institutions is of special concern to policymakers.

In an attempt to reduce the extent of disintermediation, Federal regulators of depository institutions authorized a new category of six-month time deposits called money market certificates (MMCs), which commercial banks, savings and loan associations, and

\footnotetext{
1Thrift institutions are savings and loan associations, mutual savings banks, and credit unions. The maximum interest rates which federally-regulated credit unions are allowed to offer on time and savings deposits are slightly higher than the celing rates at commercial banks, savings and loan associations, and mutual savings banks.
}

mutual savings banks were permitted to offer after June 1, 1978. This paper analyzes the role of MMCs in preventing disintermediation and the implications of continued growth of deposits through MMCs for expansion of mortgage lending and residential construction activity.

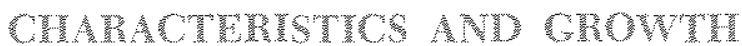 Grings}

The ceiling rate on MMCs at commercial banks is equal to the current discount yield on six-month Treasury bills; at thrift institutions, the ceiling rate is one-quarter of a percentage point higher." The rate for new $\mathrm{MMCs}$ is adjusted weekly to the yield on six-month bills at the most recent bill auction. For previously issued $\mathrm{MMCs}$, the ceiling rate remains unchanged until maturity. The minimum denomination in which MMCs are issued is $\$ 10,000$, the same as that for Treasury bills.

Around 11,700 commercial banks - approximately 79 percent of all insured commercial banks - are estimated to have been offering MMCs at the end of last year (Table I). These banks recorded an out-

\footnotetext{
${ }^{2}$ A Treasury bill has a face value which is payable by the U.S. Treasury at maturity. Investors pay various fractions of the face value of Treasury bills, the fractions reflecting maturity and discomint yield of the bills. To illustrate the calculation of discount yield, consider a one-year bill for which an investor pays 90 percent of face value. The discomt yield on that bill is 10 percent. For a Eiscussion of how discount yields may be converted to a bond equivalen basis, see footnote 4.
} 


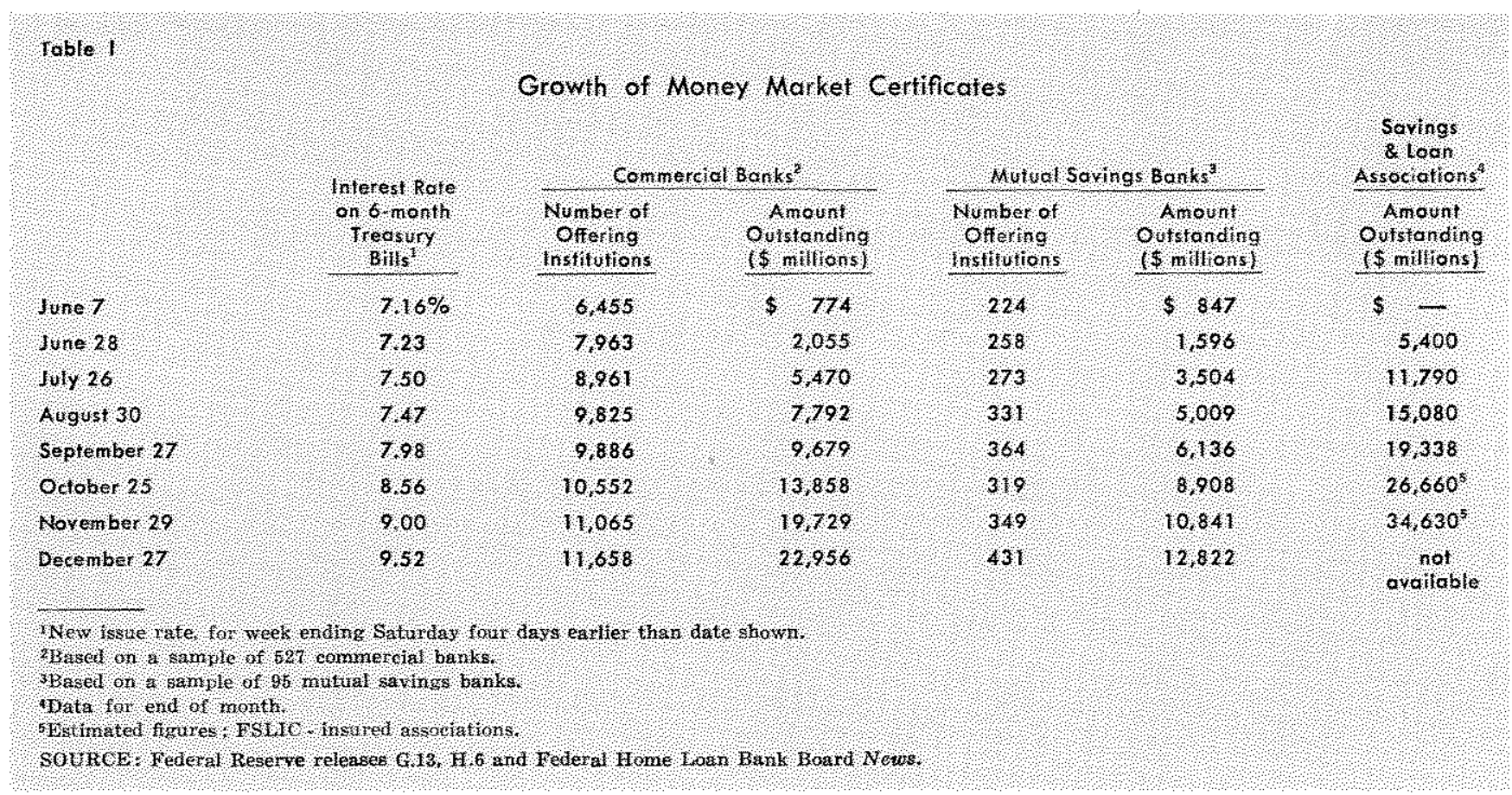

standing balance in MMCs of $\$ 23$ billion in December, representing 4.5 percent of their net time and savings deposits (not seasonally adjusted). ${ }^{3}$

Thrifts have experienced even larger growth in MMCs. Mutual savings banks are estimated to have had about $\$ 12.8$ billion of these certificates outstanding at the end of the year. At the end of November, MMCs represented 7.7 percent of total mutual savings bank deposits. Total MMCs outstanding at insured savings and loan associations is estimated to have been about $\$ 34.6$ billion in late November, or 8.3 percent of savings capital.

Growth of MMCs has had a substantial effect on deposit growth at commercial banks and thrift institutions and, thus, has enabled the institutions to avert major disintermediation. Conditions for disintermediation began to develop in 1977 when the interest rate on three-month Treasury bills (bond equivalent yield) rose above the ceiling rate on savings deposits at commercial banks in May, and above the ceiling rate on savings deposits at savings and loan associations and mutual savings banks in July (see Chart 1 ). ${ }^{4}$ By the end of 1977, market interest rates on U.S. Treasury

3Net time and savings deposits of commercial banks exclude large ( $\$ 100,000$ and over) negotiable certificates of deposit at large commercial banks.

4 Yields on Treasury bills must be converted to a bond equiv alent basis in order to compare them to interest rates on deposits. To illustrate the difference between discount and bond equivalent yields, consider a one-year Treasury bill wilh a face value of $\$ 10,000$ which is sold at a discount yield of securities were above ceiling rates on time deposits of all maturity classes at commercial banks and thrifts, and in 1978, market interest rates rose even higher relative to ceiling rates.

As a result of increases in interest rates, growth of net time and savings deposits at commercial banks slowed gradually from July 1977 through May 1978 (Table II). In contrast, growth of net time and savings deposits at commercial banks began to accelerate in June 1978, the month that MMCs became available. Deposits at thrift institutions have followed a similar pattern, with growth rates slowing from August 1977 through May 1978 and accelerating thereafter.

\section{CONMATSON TO PAS WTHODOS

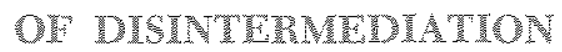

Comparison of the growth rates of deposits before and after June 1978 underestimates the full effect of MMCs in preventing disintermediation. Market interest rates have risen substantially since June 1978 ,

8 percent. The buyer would pay $\$ 9,200$ for the bill and receive $\$ 10,000$ at matmrity one year later. The bill is sold on a discount basis, meaning that the buyer pays less than the face amount, and the discount yield is determined by calculating the difference between the purchase price and the face amount as a percentage of the face amount (i.e., $\$ 800$ as a percentage of $\$ 10,000)$. Converting the discount yield to a bond equivalent yield involves calculating the difference between the purchase price and the face amomet as a percentage of the purchase price. For the Treasury bill described above, the bond equivalent yield is 8.70 percent ( $\$ 800$ as a percentage of $\$ 9,200$ ). 


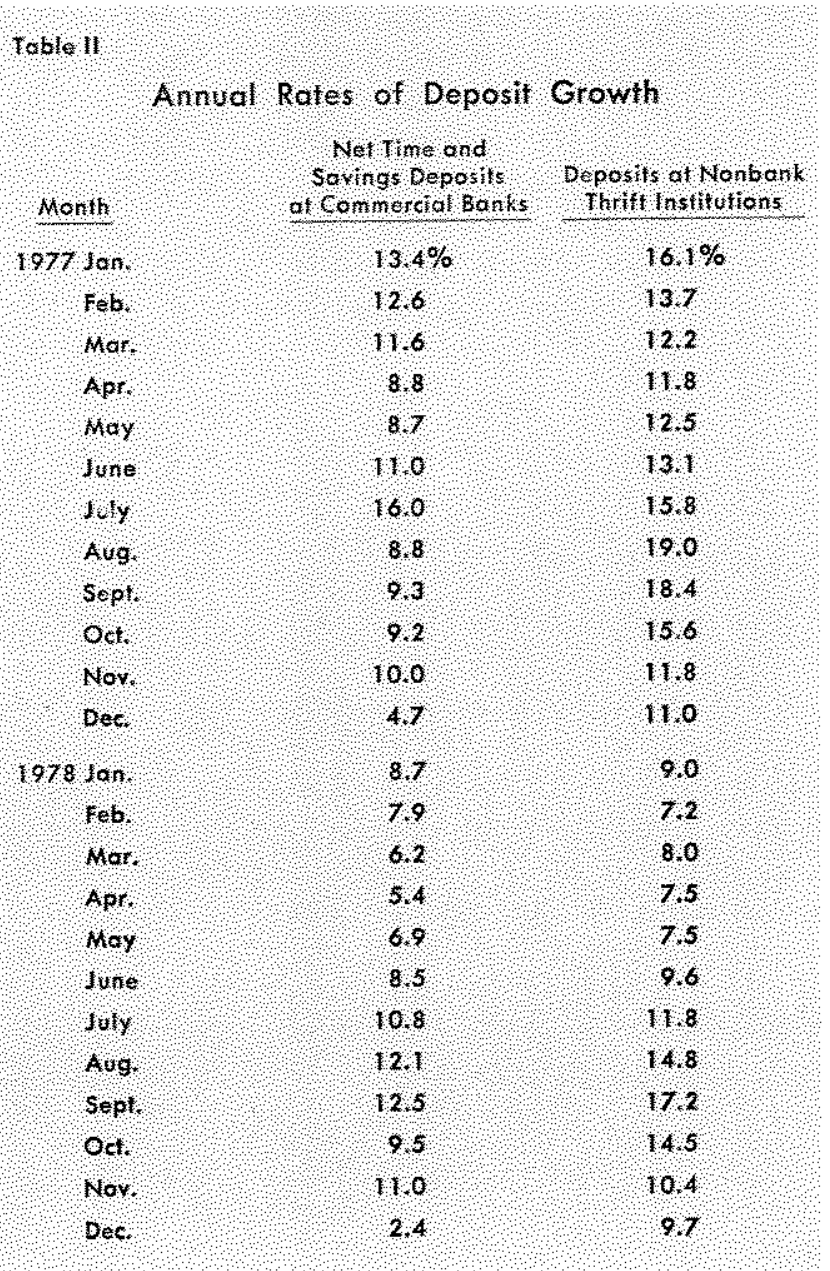

and thus the differentials between market interest rates and fixed ceiling rates on time and savings deposits have widened in recent months. Therefore, without authorization of $\mathrm{MMCs}$, and with all other ceiling rates unchanged, deposit growth would have been expected to slow substantially after June 1978.

The appropriate method of analyzing the role of MMCs in preventing disintermediation is to compare the rates of deposit growth in recent months to those of past periods when the differentials between market interest rates and fixed ceiling rates on time and saving deposits were comparable to current differentials. The historical patterns of differentials between ceiling interest rates on three categories of time and savings deposits at thrifts and market interest rates on U.S. Treasury securities of comparable maturities are presented in Charts I and II. These differentials during recent months have been similar to the prevailing differentials during parts of 1969,1973 , and 1974, when the three-month Treasury bill rate rose to more than 3 percentage points above the ceiling rate on passbook savings accounts at thrift institutions, and yields

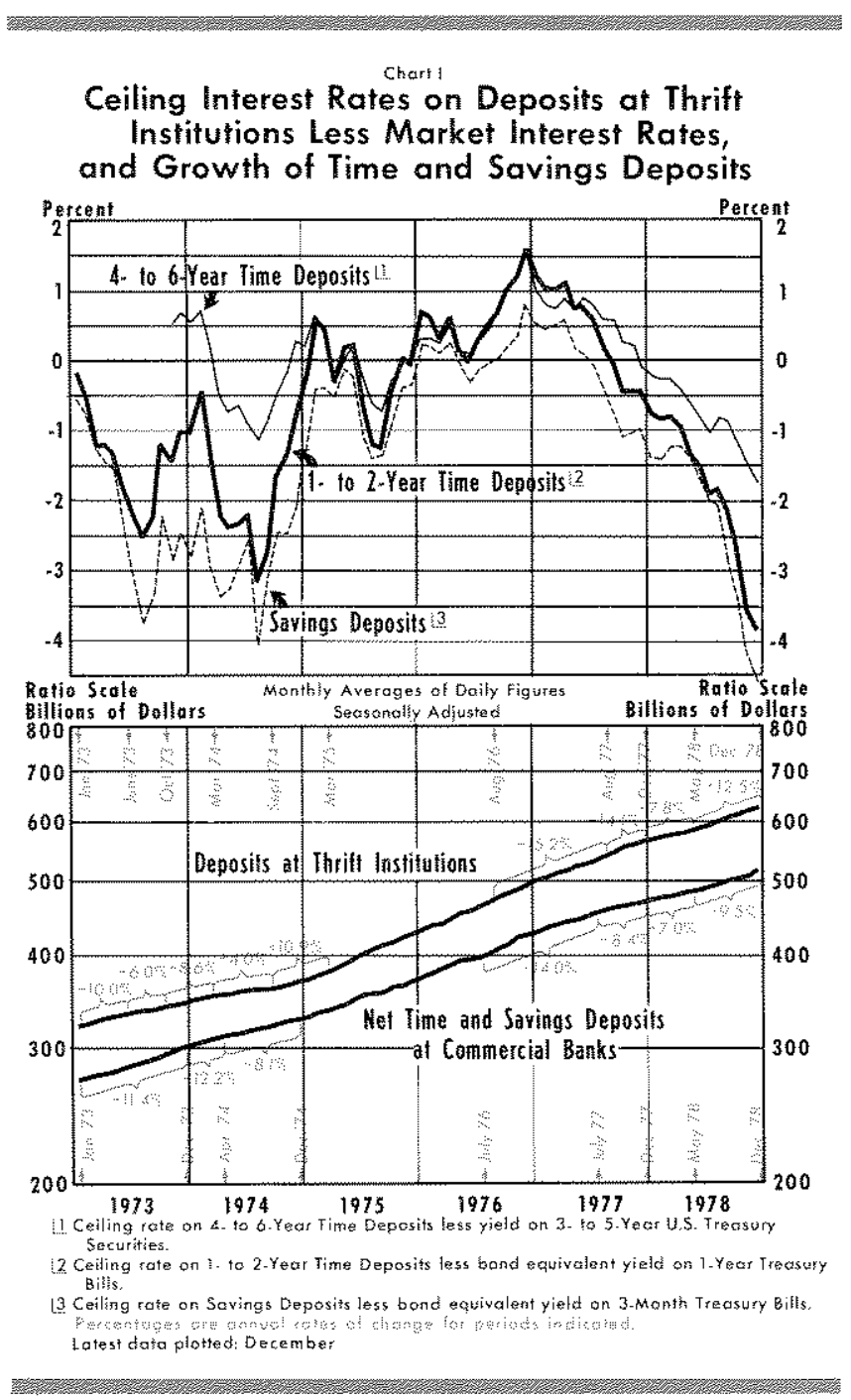

on one-year Treasury bills rose to about 2.50 percentage points above the ceiling rate on one- to twoyear time deposits.

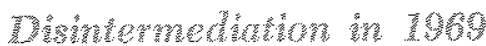

Economic activity during 1969 is comparable in several ways to economic activity in 1978 . The economy had been expanding for several years prior to 1969, and real disposable personal income rose throughout that year. Therefore, to the extent that deposit growth slowed as market interest rates rose above ceiling rates on time and savings deposits, depositors reacted to relative yields, and not to a decline in personal savings.

By early 1969 the differentials between market rates and ceiling rates were having a marked impact on deposit growth. Net time and savings deposits at com- 


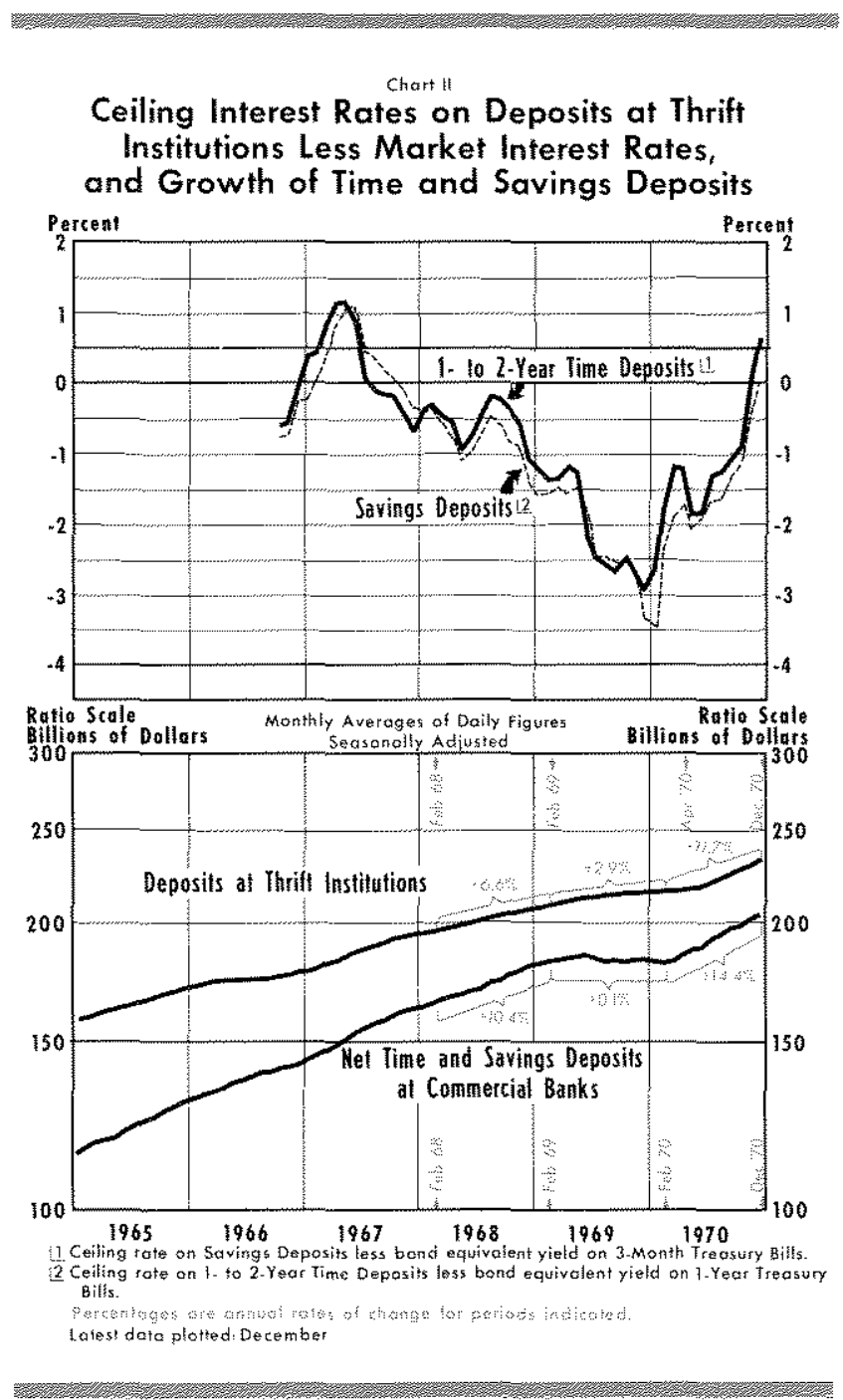

mercial banks were essentially unchanged from February 1969 to February 1970, compared to a 10 percent increase in the previous year. However, as short-term interest rates declined in 1970 , net time and savings deposits resumed rapid growth.

Growth of deposits at thrift institutions also was affected by the rise of short-term market interest rates relative to ceiling rates. From February 1969 to April 1970, deposits at nonbank thrift institutions rose at a 3 percent rate. As market interest rates declined in 1970 , growth of deposits at thrifts increased, rising at a 12 percent rate from April to December 1970 .

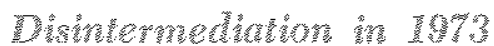

Economic activity in 1978 also was similar to that in 1973. The economy again had been expanding for several years prior to 1973 , with real disposable per- sonal income rising throughout the year. However, interest ceiling rates were changed during several months in 1973, having a significant effect on growth of deposits. The ceiling rates on time deposits of $\$ 1,000$ or more with maturities of at least four years were suspended in July 1973, thus permitting commercial banks and thrift institutions to offer competitive rates of interest on these deposits (commonly called "wild card" deposits). The ceiling rates were reinstated in November 1973.

Commercial banks were able to maintain rapid growth of net time and savings deposits during 1973 because of the significant growth in long-term time deposits, even though market interest rates were substantially above ceiling rates on savings deposits and time deposits with maturities of less than four years. Thrift institutions experienced relatively slow deposit growth for four months in 1973, possibly as a result of competition with commercial banks for "wild card" deposits. Deposits of thrifts grew at a 6 percent rate from June through October 1973, compared to a 14 percent increase in the previous year.

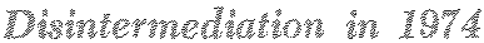

It is difficult to compare the influence of deposit interest ceilings on growth of deposits in 1978 to that in 1974 because some of the factors which influence deposit growth were different in the two years. For example, growth of personal savings, an important determinant of deposit growth at financial institutions, was slowed by the recession in 1974.5 Nevertheless, deposit interest rate ceilings also appear to have influenced the pattern of deposit growth during 1974. This effect was more pronounced at thrifts than at commercial banks.

Deposits at thrifts grew at a 4 percent rate from March through September 1974, compared to an 8.6 percent rate of increase in the previous five months. Market interest rates began declining sharply in the fall of 1974, and deposit growth increased at a 10.9 percent rate from September 1974 through March 1975, the trough month of the past recession. Thus, the rate of deposit growth increased as market interest rates declined relative to ceiling rates on time and savings deposits, even though economic activity was still dedining. This observation indicates that the slow deposit growth at thrifts during the six months

${ }^{5}$ For a survey of empirical studies on the determinants of deposits at financial institutions, see Edward $F$. McKelvey, Interest Rate Ceilings and Disintermediation, Staff Economie

Studies, Board of Governors of the Federal Reserve System (April 1978). 
ending in September 1974 was influenced not only by the effects of the recession on personal savings, but also significantly by the ceilings on deposit interest rates.

\section{Compentison to $10 \%$}

In contrast to past experience, deposit growth at commercial banks and thrifts has accelerated in recent months, even though the margins between market interest rates and ceiling rates on categories of time and saving deposits other than MMCs have been about the same as during past periods of disintermediation. The differences between growth rates of deposits in recent months and in other periods analyzed above indicate that MMCs have had a signifi cant role in preventing disintermediation.

\section{SIGNIICANCE ON MNES HOR TIE

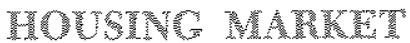

The availability of credit from thrift institutions is essential for financing residential construction. Since thrift institutions provide a major portion of both residential construction credit and residential mortgages, a reduction in deposit growth at thrifts limits the credit available to the housing market, and substantially reduces residential construction activity.

Authorization of MMCs has enabled thrift institutions to remain competitive for deposits during a period when market interest rates have been above ceiling rates on other categories of time and savings deposits. Thus, permission to offer MMCs has allowed thrift institutions to remain potential suppliers of mortgage credit, and thrifts have increased their residential mortgages substantially. During the year ending October 1978, residential mortgages held by savings and loan associations increased 14.4 percent, and mutual savings banks increased their residential mortgages 8.2 percent.

The significance of MMCs to the continuing high rate of housing starts in the current expansion can be analyzed by examining Chart III. The shaded areas represent periods when yields on three-month Treas ury bills were 100 basis points or more above ceiling rates on savings deposits at thrift institutions. In 1969-70 and 1973-74, the shaded areas correspond closely to periods of declining housing starts. In contrast, yields on three-month Treasury bills have been 100 basis points or more above the ceiling rate on

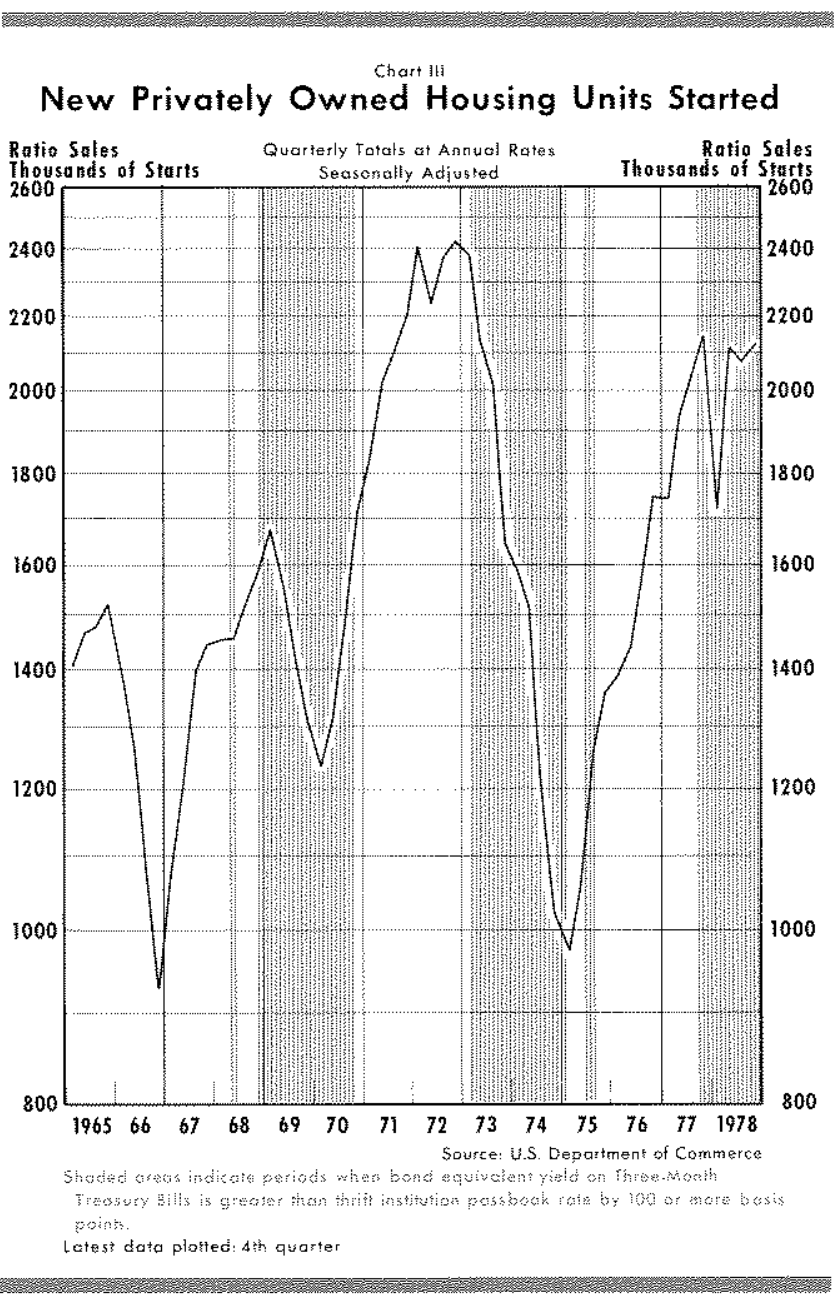

savings deposits since the fall of 1977 , yet the pace of residential construction activity remains relatively strong.

Housing starts have averaged an annual rate of about 2.1 million units in recent months, just below the highest rate of housing starts in the current expansion. This relatively high level of housing starts continues after almost four years into the current expansion. For comparison, housing starts in early 1969 peaked after a little over two years of expanding residential construction, and similarly, housing starts in late 1972 peaked two years after the previous recession trough.

However, permission for thrifts to offer MMCs does not assure a continued flow of mortgage credit. The ceiling interest rate on MMCs at thrifts is cur rently about 9.75 percent which, under daily compounding, is adjusted to about 10.25 percent. That rate is at or above the usury ceilings on residential mortgages in several states. Even in states with no usury ceilings or with usury ceilings above prevail- 
ing interest rates, the spread between rates being paid on new MMCs and the yields on new residential mortgages is relatively narrow.

With the yields on MMCs approximately the same as mortgage yields, thrifts which increase their mortgages outstanding by issuing additional MMCs may eventually experience losses on such transactions if interest rates continue to rise. Most residential mortgages remain outstanding for several years and have fixed interest rates. Deposits attracted by issuing MMCs must be reissued at prevailing interest rates every six months as they mature to avoid deposit outflows. Thrifts which make additional mortgage loans face the risk that the interest rates on their deposit liabilities will continue to rise while the yields on their assets remain fixed. Therefore, thrifts cannot determine the profitability of increasing their residential mortgages solely by comparing the yields on mortgages to cturrent interest rates on MMCs. They must consider, in addition, the possibility that interest rates will continue to rise.

Thrifts which attract additional deposits through MMCs may find investments other than residential mortgages more profitable. Although thrifts keep a relatively high proportion of their assets in residential mortgages to maintain special tax benefits, they have some margin within which they can change the mix of their assets without altering their tax status. Some thrift institutions reportedly are issuing MMCs and using those funds to buy large short-term certificates of deposit of commercial banks. ${ }^{6}$ A shift of investments by thrifts from residential mortgages to shortterm securities, however, is not yet indicated by aggregate information. In recent months, thrifts have

(6)A Surprisingly Simple CD Rollover," Business Week, Decenber 4, 1978 , pp. 84-85, and "Money Market Certificates Are Selling Woll, But Most Proceeds Aren't Going to Mortgages," Wall Street Journal, December $7,1978$. increased their holdings of mortgages at about the same rate as the increase in their deposits. ${ }^{7}$

\section{CONOHSOMS}

Deposit growth at commercial banks and thrift institutions has slowed in past periods when market interest rates rose above ceiling interest rates on time and savings deposits, a reaction called disintermediation. During the current phase of rising interest rates, Federal regulators have dealt with the threat of disintermediation by permitting commercial banks and thrift institutions to offer money market certifcates, with ceiling interest rates which change weekly in line with discount yields on six-month Treasury bills. Growth rates of net time and savings deposits at commercial banks and deposits at thrifts have increased substantially since this new category of time deposits was authorized.

Growth of deposits at thrift institutions in recent months has facilitated the rapid expansion of mortgage lending, and residential construction activity has remained at a relatively high level, especially for a period with such high interest rates. However, the continued expansion of mortgage lending and residential construction is not assured by permission for thrifts to offer MMCs. Even if thrift institutions continue to have rapid deposit growth, they will not necessarily invest these funds in residential mortgages, since other types of investment may be more profitable.

\footnotetext{
TFrom May 1978 (the month before MMCs were authorized) to November, the rate of increase in mortgages ontstanding at savings and loan associations was slightly higher thax the rate of increase in their deposits (a 6.8 percent increase in mortgages and a 5.8 percent increase in deposits). Mortgages held by mutual savings banks (MSBs) increased 3.9 percent from May to November 1978 (the latest month for which data are available), while deposits of MSBs rose 2.8 percent.
} 